\title{
STABILITY OF A MICRO-HETEROGENEOUS PLATE BAND
}

\author{
M. CHALECKI ${ }^{1}$, G. JEMIELITA ${ }^{2}$
}

\begin{abstract}
The paper presents a certain way which determines the critical buckling force for a micro-heterogeneous FGM plate band. A stiffness matrix of an individual cell of such band, different for various cells, has been determined. The obtained matrix can also be treated as a variable stiffness matrix of a "superelement" in the Finite Element Method. A computational algorithm for the critical force as well as the way of testing of its correctness has also been presented. The results obtained for various support conditions have been compared to the values known from the literature. The influence of the number of cells on the critical buckling force has been investigated.
\end{abstract}

Keywords: plate band, axial critical force, buckling, direct displacement method

\section{INTRODUCTION}

In the paper, a problem of buckling of a micro-heterogeneous FGM-like plate band with the heterogeneity of features along the direction of action of large axial forces is considered (it has been assumed in the paper that this is the direction of $x$-axis). In the second direction (y) the band is homogeneous. This problem is described by the partial differential bending equation of plate with a variable stiffness $D^{\alpha \beta \gamma \omega}$ with participation of large axial forces $S^{\alpha \beta}$ ([1] - with the assumption of zero transverse loads and compressing axial forces):

$$
\left(D^{\alpha \beta \gamma \omega} w_{\gamma \omega}\right)_{\alpha \beta}+S^{\alpha \beta} w_{, \alpha \beta}=0
$$

\footnotetext{
${ }^{1}$ PhD., Eng., Department of Civil Engineering, Warsaw University of Life Sciences (SGGW), 02-776 Warszawa, ul. Nowoursynowska 159; e-mail: marek_chalecki@sggw.pl

${ }^{2}$ Prof., DSc., PhD., Eng., Department of Civil Engineering, Warsaw University of Life Sciences (SGGW), 02-776 Warszawa, ul. Nowoursynowska 159; e-mail: g.jemielita@gazeta.pl
} 
If the band stiffness and boundary conditions do not depend on the $y$ variable, Eq. (1.1) can be written in a form:

$$
\frac{\partial^{2}}{\partial x^{2}}\left(D(x) \frac{\partial^{2}}{\partial x^{2}} w(x, t)\right)+S \frac{\partial^{2} w(x)}{\partial x^{2}}=0 .
$$

$D(x)$ denotes a plate stiffness, defined as

$$
D=\frac{E(x) h^{3}}{12\left(1-v^{2}(x)\right)} .
$$

In the case of periodically heterogeneous materials (FGM-like materials) the highly oscillating variability (jump discontinuity) of the band stiffness makes Eq. (1.2) very hard to solve (if not impossible to solve) by means of classical methods of analysis of differential equations. This problem is usually overcome by application of various techniques of homogenization - in last years mainly the tolerance averaging technique [2], but also the asymptotic homogenization, the method of effective modules, etc.

Jędrysiak [2] pondered natural vibrations of a micro-heterogeneous thin plate band with the use of the tolerance modeling, whereas Wierzbicki et al. [3] stated as follows: "From among many known ways of the modeling of problems of the mechanics of periodic media, the tolerance modeling stands out due to relative simplicity of consideration of the scale effect. This advantage of the tolerance modeling resulted in the description and solution of many problems of the mechanics of heterogeneous media. Unfortunately, we can obtain here only approximate solutions, for which we do not know effective methods to evaluate the accuracy of the obtained solutions".

Disagreeing with the above statement, the Authors decided to prove that in the case of the problems presented in [2], [4], [5], [8], [9] a solution can be obtained which is exact [6] or formally exact [7] within the framework of the theory of thin plates.

The microperiodic FGM-like plate band is modeled as a system with properties changing in a discrete way between two levels - micro and macro. This paper presents that it is possible to obtain an exact solution to the problem of seeking of critical buckling force with the use of methods of structural mechanics. The aim of the paper is the exact calculation of the critical buckling force for a thin plate band with a microstructure showed in Fig. 1. According to the Author's knowledge, there are no items in the accessible literature where the problem of buckling of such band would be solved in the way allowing obtaining an exact solution. 


\section{BASIC ASSUMPTIONS}

Let us consider a Kirchhoff's plate band with the width $L$ and thickness $h$, having a microstructure presented in Fig. 1. Along the $x$-axis, the plate band consists of $N$ bands (cells, elements) with a constant width equal to

$$
l=\frac{L}{N} .
$$

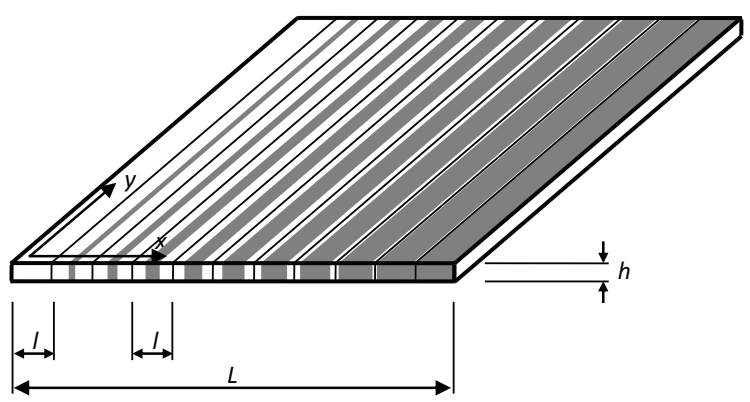

Fig 1. Plate band with FGM-like microstructure

Each band (cell) with the width $l$ consists of three parts (subcells) and two materials: 1 (matrix) and 2 (inclusion) with stiffnesses $D_{1}$ i $D_{2}$ respectively (Fig. 2), wherein

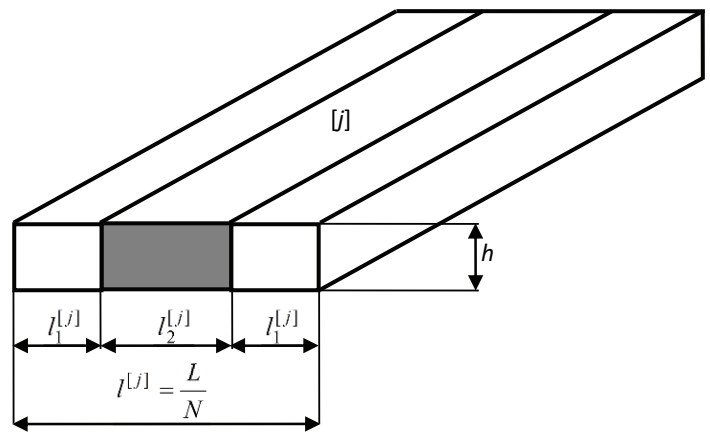

Fig 2. Dimensions of the cell of a number $[j]$ 


$$
D_{1}=D=\frac{E_{1} h^{3}}{12\left(1-v_{1}^{2}\right)}=\frac{E h^{3}}{12\left(1-v^{2}\right)}, D_{2}=\eta D, D>0, \eta>0
$$

and $\eta$ denotes a stiffness coefficient (any positive non-zero real number).

The widths of the band element $l_{1}^{[j]}, l_{2}^{[j]}$ are calculated as:

$$
l_{1}^{[j]}=\xi_{1}^{[j]} l, l_{2}^{[j]}=\xi_{2}^{[j]} l
$$

The fraction coefficients $\xi_{1}^{[j]}, \xi_{2}^{[j]}$ and the width $l^{[j]}$ of the band element are determined from the formulas

$$
\xi_{1}^{[j]}=\frac{1}{2}\left(1-\frac{j-1}{N-1}\right), \xi_{2}^{[j]}=\frac{j-1}{N-1}, j=1,2,3, \ldots, N, l=2 l_{1}^{[j]}+l_{2}^{[j]}=\frac{L}{N}
$$

A band element with the width $l^{[j]}$ can be treated as a bar element with the section $F=h \times b$, $b=1 \mathrm{~m}$. To obtain the critical buckling force for the microperiodic band with the width $L$, the stiffness matrix for a typical bar element (cell) with the length $l^{[j]}=2 l_{1}^{[j]}+l_{2}^{[j]}$ is to be determined.

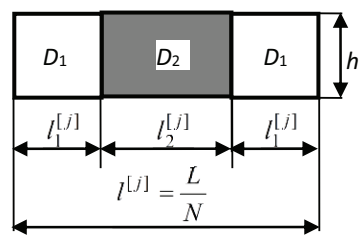

Fig 3. Dimensions of the bar superelement

As a typical band element with the width $l^{[j]}$ consists of three bands with a various width, the bar element with the width $l^{[j]}$ will be denoted as "superelement" consisting of three elements (Fig. 3). 


\section{STIFFNESS MATRIX OF A BAND ELEMENT $[J]$}

Let us consider a bar element fixed on both ends, the bar having a jump-type variable stiffness and whose nodes $(j-1)$ and $(j)$ are subjected to displacements (rotations and relocations) $\varphi_{j-1}^{[j]}, \varphi_{j}^{[j]}$, $w_{j-1}^{[j]}, w_{j}^{[j]}$ (Fig.4).

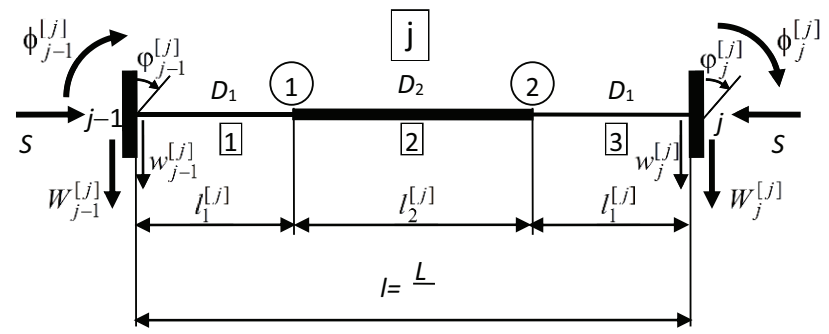

Fig 4. Computational model of the superelement (band element - periodicity cell)

Using the well known stiffness matrices of the bar element fixed on both sides (transformation formulas), after the elimination of the rotation angles and relocations of the nodes 1 and 2 of the element $[j]$, we obtain the following dependence between the node forces $\phi_{j-1}^{[j]}, \phi_{j}^{[j]}, W_{j-1}^{[j]}, W_{j}^{[j]}$ and the rotation angles $\varphi_{j-1}^{[j]}, \varphi_{j}^{[j]}$ as well as the relocations $w_{j-1}^{[j]}, w_{j}^{[j]}$ :

$$
\boldsymbol{\Phi}^{[j]}=\mathbf{K}^{[j]} \boldsymbol{\varphi}^{[j]},
$$

where

$$
\begin{gathered}
\mathbf{K}^{[j]}=\left[\begin{array}{ccc}
k_{11} & k_{12} & -k_{13} \\
k_{12} & k_{22} & -k_{13} \\
-k_{13} & -k_{13} & k_{33}
\end{array}\right], \boldsymbol{\Phi}^{[j]}=\left[\begin{array}{c}
\phi_{j-1}^{[j]} \\
\phi_{j}^{[j]} \\
l W_{j-1}^{[j]}
\end{array}\right], \boldsymbol{\varphi}^{[j]}=\left[\begin{array}{c}
\varphi_{j-1} \\
\varphi_{j} \\
\psi^{[j]}
\end{array}\right] \\
\psi^{[j]}=2\left(\psi_{j}^{[j]}-\psi_{j-1}^{[j]}\right), l W_{j}^{[j]}=-l W_{j-1}^{[j]}, \psi_{j-1}^{[j]}=\frac{w_{j-1}}{l}, \psi_{j}^{[j]}=\frac{w_{j}}{l}, \\
k_{11}=-\frac{\beta_{1}^{[j]} B_{1}^{[j]}}{(n-j) \xi_{1}^{[j]}}+\frac{\theta_{1}^{[j]} B_{2}^{[j]}}{4\left(\xi_{1}^{[j]}\right)^{3}}, k_{12}=-\frac{\beta_{1}^{[j]} A_{1}^{[j]}}{(n-j) \xi_{1}^{[j]}}+\frac{\alpha_{1}^{[j]}}{2 \xi_{1}^{[j]}}+\frac{\theta_{1}^{[j]} A_{2}^{[j]}}{4\left(\xi_{1}^{[j]}\right)^{3}},
\end{gathered}
$$




$$
\begin{gathered}
k_{13}=-\frac{C_{1}^{[j]} \beta_{1}^{[j]}}{8(k-1)\left(\xi_{1}^{[j]}\right)^{2}}+\frac{\theta_{1}^{[j]}}{4\left(\xi_{1}^{[j]}\right)^{2}}\left(1-\frac{C_{2}^{[j]}}{2}\right) \\
k_{33}=\frac{C_{1}^{[j]} \theta_{1}^{[j]}}{16(j-1)\left(\xi_{1}^{[j]}\right)^{3}}-\frac{1}{8\left(\xi_{1}^{[j]}\right)^{4}}\left(2 \theta_{1}^{[j]}-\left(\sigma_{1}^{[j]}\right)^{2}\right)\left(1-\frac{C_{2}^{[j]}}{2}\right)
\end{gathered}
$$

The functions $\alpha_{k}^{[j]}, \beta_{k}^{[j]}, \theta_{k}^{[j]}$ are described as $(k=1,2)$

$$
\begin{gathered}
\alpha_{k}^{[j]}=\sigma_{k}^{[j]} \frac{\sin \sigma_{k}^{[j]}-\sigma_{k}^{[j]} \cos \sigma_{k}^{[j]}}{2\left(1-\cos \sigma_{k}^{[j]}\right)-\sigma_{k}^{[j]} \sin \sigma_{k}^{[j]}}, \beta_{k}^{[j]}=\sigma_{k}^{[j]} \frac{\sigma_{k}^{[j]}-\sin \sigma_{k}^{[j]}}{2\left(1-\cos \sigma_{k}^{[j]}\right)-\sigma_{k}^{[j]} \sin \sigma_{k}^{[j]}}, \\
\theta_{k}^{[j]}=\alpha_{k}^{[j]}+\beta_{k}^{[j]}
\end{gathered}
$$

where

$$
\sigma_{1}^{[j]}=\xi_{1}^{[j]} \sigma, \sigma_{2}^{[j]}=\xi_{2}^{[j]} \sigma \sqrt{\frac{1}{\eta}}, \sigma=l \sqrt{\frac{S}{D}},
$$

$D$ is measured in Nm, $\sigma$ is a dimensionless quantity and $S$ is a critical buckling force being sought.

The coefficients $A_{1}^{[j]}, A_{2}^{[j]}, B_{1}^{[j]}, B_{2}^{[j]}, C_{1}^{[j]}, C_{2}^{[j]}$ for a given element (cell) of a number $j$ depend on the parameters $j, N, \eta$. The form of these coefficients is quite complicated (each of them occupies ca. $3 / 4 \div 1$ side of A4 sheet), therefore the formulas for these coefficients will not be presented in this paper.

\section{BAND STIFFNESS MATRIX}

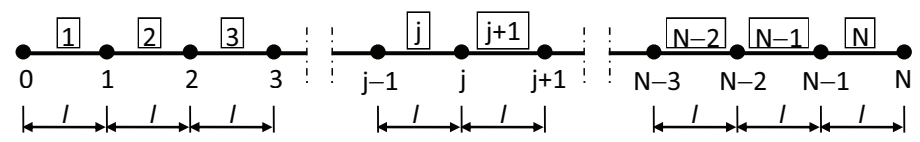

Fig. 5. Schematic section of a plate band 
The band under consideration consists of $N$ elements with $N+1$ nodes. Fig. 5 schematically shows a band section with $N$ cells. The unknowns are generalized node displacements $\varphi_{j}, w_{j}$ or $\varphi_{j}$, $\psi_{j}=w_{j} / l$. For any node $j(1 \leq j \leq N-1)$, two equilibrium equations can be written

$$
\phi_{j}^{[j]}+\phi_{j}^{[j+1]}=0, W_{j}^{[j]}+W_{j}^{[j+1]}=0, j=1,2,3, \ldots, N-1,
$$

which comprise five unknown generalized displacements $\varphi_{j-1}, \varphi_{j}, \varphi_{j+1}, \psi^{[j]}, \psi^{[j+1]}$. Finally we obtain the set of $2(N-1)$ equations with $2(N-1)$ unknowns. This set will be written in the form

$$
\mathbf{K} \boldsymbol{\varphi}=0, \operatorname{dim} \mathbf{K}=2(N-1) \times 2(N-1), \operatorname{dim} \boldsymbol{\varphi}=2(N-1) \times 1,
$$

where $\mathbf{K}$ is the band stiffness matrix with the elements being a function of a value of $\sigma$ being sought (given by formula (3.6) 3 ), whereas $\varphi$ is a one-column matrix of generalized displacements.

The structure of the matrices $\mathbf{K}$ and $\boldsymbol{\varphi}$ is presented below (the empty cells are equal 0 ). As the matrix $\mathbf{K}$ is symmetric, we present only its upper part.

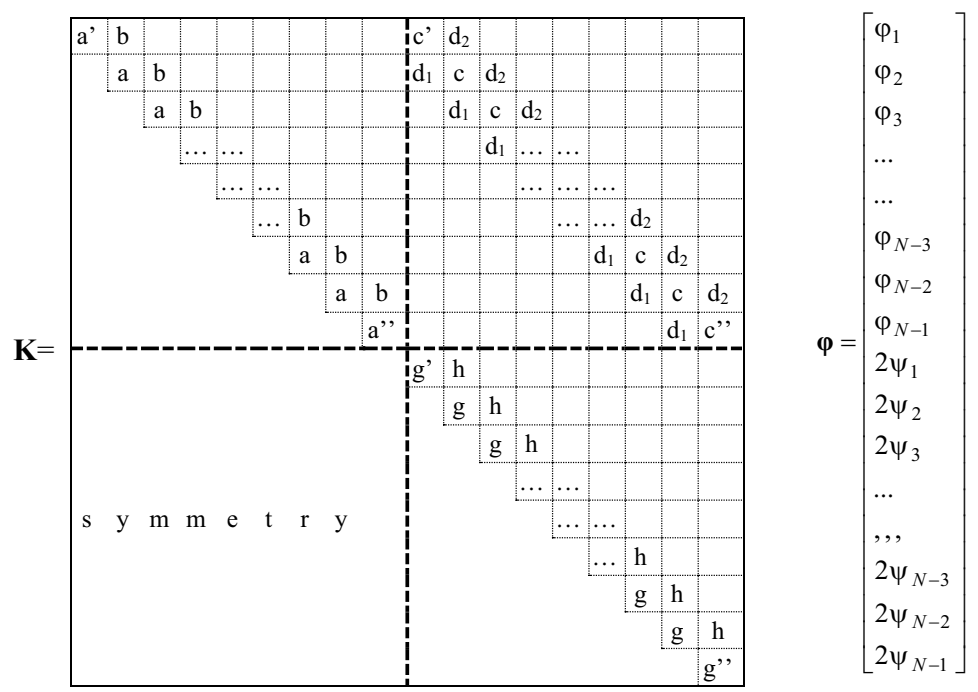


The matrix $\mathbf{K}$ consists of four band submatrices. Individual terms are equal:

$$
\begin{gathered}
a^{(i)}=k_{12}^{(i)}+k_{12}^{(i+1)}, a^{\prime}=\frac{1}{2} \alpha_{p}+k_{12}^{(2)}, a^{\prime \prime}=\frac{1}{2} \eta \alpha_{k}+k_{12}^{(N-1)}, b^{(i)}=k_{11}^{(i)}, \\
c^{(i)}=k_{13}^{(i)}+k_{13}^{(i+1)}, c^{\prime}=-\frac{1}{4} \theta_{p}+k_{13}^{(2)}, c^{\prime \prime}=\frac{1}{4} \eta \theta_{k}+k_{13}^{(N-1)}, d_{1}^{(i)}=k_{13}^{(i)}, d_{2}^{(i)}=k_{13}^{(i+1)}, \\
e^{(i)}=k_{13}^{(i)}+k_{13}^{(i+1)}, e^{\prime}=-\frac{1}{4} \theta_{p}+k_{13}^{(2)}, e^{\prime \prime}=\frac{1}{4} \eta \theta_{k}+k_{13}^{(N-1)}, f_{1}^{(i)}=k_{13}^{(i)}, f_{2}^{(i)}=k_{13}^{(i+1)}, \\
g^{(i)}=k_{33}^{(i)}+k_{33}^{(i+1)}, g^{\prime}=\frac{1}{8} \delta_{p}+k_{33}^{(2)}, g^{\prime \prime}=\frac{1}{8} \eta \delta_{k}+k_{33}^{(N-1)}, h^{(i)}=k_{13}^{(i)}
\end{gathered}
$$

where the superscript in the terms $a \div h$ denotes the submatrix row number and in the terms $k-$ the band cell (element) number (hence, e.g. the term $f_{1}$ is in the $3^{\text {rd }}$ row of the lower left submatrix, so it requires to take the term $k_{13}$ for the cell with $j=3$, whereas the term $f_{2}$ in the same row - the term $k_{13}$ for the cell with $j=4$ ). The terms $k$ are given by Eqs (3.4).

Special attention must be paid to the first and the last element, i.e. for $j=1$ and $j=N$. The terms $\xi_{1}$ and $\xi_{2}$ take the value (Eqs (2.3)): for $j=1 \xi_{1}=\frac{1}{2 N}, \xi_{2}=0$; for $j=N \xi_{1}=0, \xi_{2}=\frac{1}{N}$. The first cell has the constant stiffness $D$, the last one - the constant stiffness $D_{2}=\eta D$. Moreover, these cells in general are not supported as in Fig. 3 because the left support of the first cell (point 0 in Fig. 5 ) and the right support of the last one (point $N$ in Fig. 5) can be supported in any way. For the transformation formulas for the first and the last cell, depending on their supports.

The terms $a^{\prime}, a^{\prime \prime}, c^{\prime}, c^{\prime \prime}, e^{\prime}, e^{\prime \prime}, g^{\prime}, g^{\prime \prime}$ concern the first and the last cell. Depending on support conditions, the coefficients $\alpha \div \delta$ contained there are equal:

- for a fixed boundary:

$$
\alpha_{p}=\alpha(\sigma), \alpha_{k}=\alpha\left(\frac{\sigma}{\sqrt{\eta}}\right), \theta_{p}=\theta(\sigma), \theta_{k}=\theta\left(\frac{\sigma}{\sqrt{\eta}}\right), \delta_{p}=2 \theta(\sigma)-\sigma^{2}, \delta_{k}=2 \theta\left(\frac{\sigma}{\sqrt{\eta}}\right)-\frac{\sigma^{2}}{\eta},
$$

- for a hinged boundary:

$$
\alpha_{p}=\theta_{p}=\alpha^{\prime}(\sigma), \alpha_{k}=\theta_{k}=\alpha^{\prime}\left(\frac{\sigma}{\sqrt{\eta}}\right), \delta_{p}=\alpha^{\prime}(\sigma)-\sigma^{2}, \delta_{k}=\alpha^{\prime}\left(\frac{\sigma}{\sqrt{\eta}}\right)-\frac{\sigma^{2}}{\eta},
$$


- for a fixed boundary with the possibility of transverse movement:

$$
\alpha_{p}=\alpha^{\prime \prime}(\sigma), \alpha_{k}=\alpha^{\prime \prime}\left(\frac{\sigma}{\sqrt{\eta}}\right), \theta_{p}=\theta_{k}=\delta_{p}=\delta_{k}=0,
$$

- for a free boundary:

$$
\alpha_{p}=\alpha^{\prime \prime \prime}(\sigma), \alpha_{k}=\alpha^{\prime \prime \prime}\left(\frac{\sigma}{\sqrt{\eta}}\right), \theta_{p}=\theta_{k}=\delta_{p}=\delta_{k}=0,
$$

where $\alpha$ and $\theta$ are given by Eqs (3.4), whereas: $\alpha^{\prime}=\frac{\sigma^{2} \sin \sigma}{\sin \sigma-\sigma \cos \sigma}, \alpha "=\sigma \operatorname{ctg} \sigma, \alpha ", "=-\sigma \operatorname{tg} \sigma$.

\section{DETERMINATION OF APPROXIMATED VALUE}

\section{OF CRITICAL BUCKLING FORCE}

From the condition $\operatorname{Det} \mathbf{K}=0$, for the given $N$ and $\eta$, we can determine the value of $\sigma$ and then from the Eq. (3.2) - values of critical buckling force. For a microperiodic plate band, the matrix $\mathbf{K}$ is in general of large size, its terms depend on the quantities given by Eqs (3.4) in a very complicated way and additionally those quantities depend on the value of $\sigma$, so the functional dependence $f(\sigma)=\operatorname{Det} \mathbf{K}$ is extremely intricate and the determination of subsequent zeros can take a lot of time even for computers with a good processor (but the most probable is that the calculations will shut down due to complete occupancy of operational memory). Therefore, the best way is to assume an initial value $\sigma_{0}$ for the given parameters $\eta, N$ and, for a given step of increase of this initial value, after the determinant value has changed the sign, apply the secant method for finding such a value of $\sigma_{k r}$ which implies $\operatorname{Det} \mathbf{K}\left(\sigma_{k}\right) \cong 0$. This value can be determined with any required accuracy.

Having the critical value $\sigma_{k r}$ determined, the critical buckling force can be calculated from formulas $(3.6)_{3}$ and (2.1) which yield

$$
S_{k r}=\sigma_{k r}^{2} \frac{D}{l^{2}}=\sigma_{k r}^{2} \frac{N^{2}}{L^{2}} D
$$


where $D$ - according to Fig. 2 and formulas (2.2) - is the stiffness of the first subcell and the reference stiffness.

As example, the calculations for a 6-cell plate $(N=6)$ fixed on the left end and supported on hinge on the right end were performed (Fig. 6a). The stiffness coefficient was taken as $\eta=5$. It can be estimated with high accuracy that $\operatorname{Det} \mathbf{K}=0$ for $\sigma_{a k r}=0,97805$ hence the critical force is equal (cf. Eq. (5.1))

$$
S_{a k r}=34.437 \frac{D}{L^{2}}
$$

Next, for the plate with similar support conditions but fixed on the right end and supported on hinge on the left end (Fig. 6b) the value $\sigma=0,99916$ is obtained and the critical force is equal

$$
S_{b k r}=35.939 \frac{D}{L^{2}}
$$

The obtained result corresponds with engineer's intuition because the more flexible element is placed at the fixing of the plate in Fig. 6a than at the fixing of that in Fig. 6b, thus this second plate should be characterized by a higher critical force.

a)

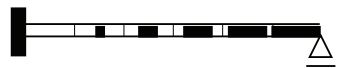

b)

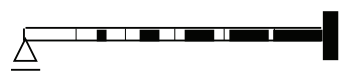

Fig. 6. The bands fixed on the one end and supported on hinge on the another end

Similarly, for the plate band with $N=8$ and $\eta=5$ the results are

$$
\sigma_{a k r}=0.73185, S_{a k r}=34.279 \frac{D}{L^{2}}, \sigma_{b k r}=0.74908, S_{a k r}=35.911 \frac{D}{L^{2}} .
$$

For the plates presented in Fig. 7, exactly the same results will be obtained provided the fraction coefficients (2.3) have the form

$$
\xi_{1}^{[j]}=\frac{1}{2}\left(1-\frac{N-j}{N-1}\right), \xi_{2}^{[j]}=\frac{N-j}{N-1}, j=1,2, \ldots, N
$$


a)

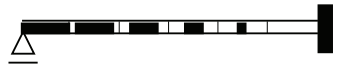

b)

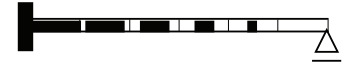

Fig. 7. Plates with the fraction coefficients given by Formula (5.4)

Several tests were performed to check if the proposed solution of the problem is correct. Assuming $\eta=1$ (homogeneous band) one obtains the graphs analogical to those from Fig. 6, depending on the way of supporting of the band. In this case, the exact values of buckling critical forces are well known and equal

$$
S_{0 k r}=\sigma_{0 k r}^{2} \frac{D}{L^{2}},
$$

wherein the coefficient $\sigma_{0 k r}$ depends on the way of supporting.

Assuming, for example, $N=8$, if the proposed solving algorithm is correct, then the values of $\sigma_{k r}$ have to be exactly 8 times lower than the known values $\sigma_{0 k r}$ and the values of critical buckling forces calculated from formula (5.1) have to be equal to those calculated from formula (5.5). The tests presented in Fig. 8 confirm the correctness of the proposed algorithm of the solution of the problem of seeking of critical buckling force of a heterogeneous band.

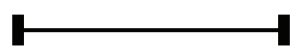

a) $\sigma=0,7854, \sigma_{0}=2 \pi$

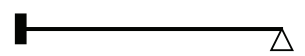

c) $\sigma=0,5617, \sigma_{0}=4,4930\left(\sigma_{0}=\tan \sigma_{0}\right)$

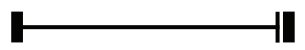

e) $\sigma=0,3927, \sigma_{0}=\pi$,

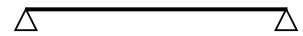

b) $\sigma=0,3927, \sigma_{0}=\pi$

d) $\sigma=0,1963, \sigma_{0}=\pi / 2$

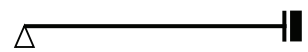

f) $\sigma=0,1963, \sigma_{0}=\pi / 2$.

Fig. 7. Values of the $\sigma_{k r}$ and $\sigma_{0 k r}$ for homogeneous bands supported as on the schemes

The dependence of critical buckling force $S$ on the number of cells $N$ and on the stiffness coefficient $\eta$ was also investigated (the band - as in Fig. 6a). In every case the critical buckling force for a band is calculated from the formula (cf. Eqs (2.1) and (5.1)). If $D$ and $L$ are given, the variability of the first value of critical buckling force can be investigated as the variability of a product $\sigma^{2} N^{2}$. Fig. 
8 shows the dependence $S_{k r} \frac{L^{2}}{D}$ on the number of cells $N$ and the stiffness coefficient $\eta$. Following values were assumed: $N=[3,4,5,7,9], \eta=[1 / 3 ; 1 / 2 ; 1 ; 2 ; 3 ; 5 ; 7]$.

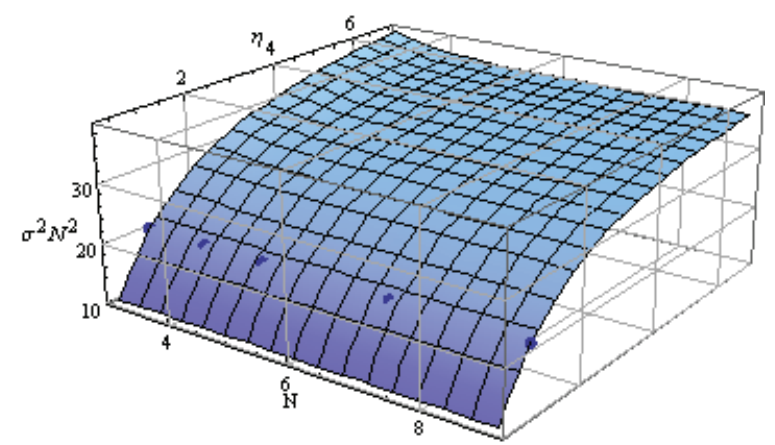

Fig. 8. Function $S_{k r} \frac{L^{2}}{D}=f(N, \eta)$. The dots denote the value of $\sigma^{2} N^{2}$ for $\eta=1$,

which falls into the range 20,1906 to 20,1911 (exact result: 20,1907)

It is visible in Fig. 8 that if the number of cells $(N)$ varies then the change of critical force is slight. Some disturbances exist for very small number of cells $(N=3)$, but it is acceptable because the methods of homogenization bring in significant errors as well if the number of cells is small calculations for $N>3$ are advised. If the inclusion stiffness $(\eta)$ increases, the critical force also increases which corresponds with an engineer's intuition. The values of the $S_{k r} \frac{L^{2}}{D}$ for $\eta=1$, i.e. for a homogeneous band, are also marked on the Figure: they are practically equal $4,49344^{2}=$ $=20,1907$, where 4,44934 is the value of $\sigma_{k r}$ for a homogeneous band fixed on one end and supported at hinge on another. 


\section{Conclusions}

The presented method of investigation of stability of micro-heterogeneous plate band is based on a classical method of the structural mechanics and allows to obtain in a relatively fast way, with requested accuracy, the value of a critical buckling force through any change of the parameter $\eta$, characterizing the inclusion stiffness in relation to the matrix stiffness, and $N$ - the number of cells in a band with the length $L$.

All tests performed in aim to check the algorithm's correctness confirmed the engineer's intuition and theoretical dependences. Namely, it was proven that:

- a critical buckling force $(S)$ depends on a number of cells $(N)$ to a minor degree but increases along with the growth of inclusion stiffness (stiffness coefficient $-\eta$ ),

- in the case of a homogeneous band (assumption $\eta=1$ ), the known exact results are obtained,

- the algorithm does not show differences if the global coordinate system is reversed, i.e. it does not matter if the beginning of the band is assumed at its left end or right end.

The above-mentioned conclusions prove the correctness of the created calculation algorithm. A similar algorithm also concerns plate bands where the inclusion stiffness varies not proportionally to a cell number but according to any function - it only demands to choose fraction coefficients $\xi$ (Eqs 2.3) in a proper way.

\section{REFERENCES}

1. G. Jemielita, Theories of elastic plates. In: Cz. Woźniak (ed.), Technical Mechanics, Vol. 8. Mechanics of elastic plates and shells [in Polish], pp. 148-330, Warszawa, PWN, 2001.

2. J. Jędrysiak, Drgania swobodne mikroniejednorodnego cienkiego pasma płytowego. In: G. Jemielita (ed.), Modellling of structures and engineering constructions [in Polish], pp. 133-139, Warszawa, SGGW, 2014

3. E. Wierzbicki, D. Kula, M. Mazewska, On Fourier realization of the tolerance modelling of heat conduction problems for simple periodic composites. In: G. Jemielita (ed.), Modellling of structures and engineering constructions [in Polish], pp. 253-266, Warszawa, SGGW, 2014

4. B. Michalak, Stability Of Elastic Slightly Wrinkled Plates, Acta Mechanica, 130, 111-119, 1998.

5. E. Baron, On A Certain Model Of Uniperiodic Medium Thickness Plates Subjected To Initial Stresses, J. Theor. App. Mech. 43, 1, 93-110, 2005

6. M. Chalecki, G. Jemielita, Drgania własne mikroniejednorodnego pasma płytowego. In: G. Jemielita (ed.), Modellling of structures and engineering constructions [in Polish], , Warszawa, SGGW, 2014

7. G. Jemielita, Solutions to the problems of mechanics of non-homogeneous beams and plates. In: K. Wilmański (ed.), Mathematical methods in continuum mechanics, pp. 383-402, Łódź, Technical University of Łódź, 2011 
8. J. Rychlewska, Cz. Woźniak, M. Woźniak, Modelling Of Functionally Graded Laminates Revisited, Electronic Journal of Polish Agricultural Universities, 9(2) \#06, 2006

9. J. Jędrysiak, On stability of thin periodic plates. Eur.J.Mech.A/Solids, 19, 487-502, 2000.

Received 14.08. 2015

Revised 28.09. 2015

\section{LIST OF FIGURES AND TABLES:}

Fig. 1. Plate band with FGM-like microstructure

Rys. 1. Pasmo płytowe o strukturze niejednorodnej typu FGM

Fig. 2. Dimensions of the cell of a number $[j]$

Rys. 2. Wymiary komórki o numerze $[j]$

Fig. 3. Dimensions of the bar superelement

Rys. 3. Wymiary superelementu prętowego

Fig. 4. Computational model of the superelement (band element - periodicity cell)

Rys. 4. Model obliczeniowy superelementu (element pasma - komórki niejednorodności)

Fig. 5. Schematic section of a plate band

Rys. 5. Schematyczny odcinek pasma płytowego

Fig. 6. The bands fixed on the one end and supported on hinge on the another end

Rys. 7. Pasma utwierdzone po jednej stronie i podparte przegubowo po drugiej

Fig. 7. Plates with the fraction coefficients given by Formula (5.4)

Rys. 7. Pasma o współczynnikach frakcyjnych wyrażonych wz. (5.4)

Fig. 8. Function $S_{k r} \frac{L^{2}}{D}=f(N, \eta)$. The dots denote the value of $\sigma^{2} N^{2}$ for $\eta=1$, which falls into the range 20,1906 to 20,1911 (exact result: 20,1907)

Rys. 8. Funkcja $S_{k r} \frac{L^{2}}{D}=f(N, \eta)$. Kropki oznaczają wartość $\sigma^{2} N^{2}$ dla $\eta=1$, która mieści się w przedziale od 20,1906 do 20,1911 (wynik dokładny: 20,1907) 


\section{2nd StATECZNoŚĆ MIKRONIEJEDNORODNEGO PASMA PLYTOWEGo}

3. Slowa kluczowe: pasmo płytowe, osiowe siły krytyczne, wyboczenie, metoda przemieszczeń

\section{STRESZCZENIE}

W pracy rozpatrzono model mikroniejednorodnego pasma płytowego o funkcyjnej gradacji własności wzdłuż kierunku działania dużych sił osiowych (przyjęto, że jest to kierunek $x$ ). Własności mechaniczne pasma nie zależą od drugiego kierunku $(y)$. Wyznaczono wartości krytyczne tych sił, przy których nastąpi utrata stateczności pasma.

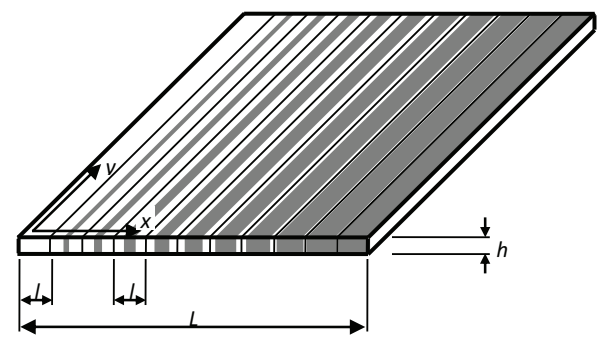

Rys. 1. Pasmo płytowe z mikrostrukturą

Przy założeniu stałej grubości pasma $(h)$ i zmiennych skokowo wzdłuż osi $(x)$ własności materiałowych podstawowej komórki (rys. 2), można wyznaczyć ściśle siłę krytyczną dla takiego pasma korzystając z równań teorii płyt cienkich. W pracy pokazano możliwość uzyskania ścisłego rozwiązania zasygnalizowanego zagadnienia, korzystając z metod mechaniki budowli. Problemy tego typu były do tej pory badane za pomocą technik homogenizacji (np. uśredniania tolerancyjnego - p. [2]), zaś metody mechaniki budowli (metodę przemieszczeń) zastosowano w [1] do badania drgań swobodnych pasma mikroniejednorodnego.

Celem pracy jest ścisłe wyznaczenie siły krytycznej dla cienkiego pasma płytowego o mikrostrukturze pokazanej na rys. 1. Pasmo wzdłuż zmiennej $x$ składa się z $N$ komórek o stałej długości $l=L / N$. Każda komórka złożona jest z trzech części - dwóch materiałów o sztywnościach $D_{1}, D_{2}$ (rys. 2). Przyjęto, że szerokości komórek $l_{1}^{[j]}, l_{2}^{[j]}$ są zmienne i dla dowolnej komórki określone wzorami

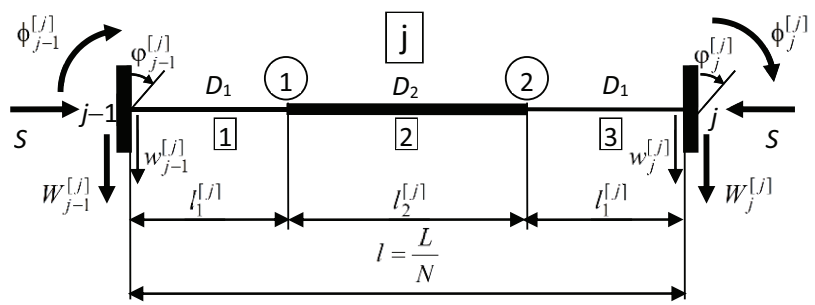

Rys. 2. Model obliczeniowy superelementu (komórki periodyczności) 


$$
l_{1}^{[j]}=\frac{1}{2}\left(1-\frac{j-1}{N-1}\right) l, l_{2}^{[j]}=\frac{j-1}{N-1} l, l=2 l_{1}^{[j]}+l_{2}^{[j]}=\frac{L}{N}, D_{1}=D=\frac{E h^{3}}{12\left(1-v^{2}\right)}, D_{2}=\eta D, D>0
$$

gdzie $\eta$ - dowolna liczba rzeczywista większa od zera.

W celu uzyskania siły krytycznej powodującej utratę stateczności pasma należy wyznaczyć macierz sztywności typowego elementu (komórki) prętowego o długości $l=2 l_{1}+l_{2}$.

Obustronnie utwierdzoną komórkę pasma możemy traktować, jako prętowy element skończony (superelement) złożony z trzech elementów, o zmiennej skokowo sztywności. Brzegi tego elementu doznają amplitud przemieszczeń (obrotów i przesunięć) $\varphi_{i-1}^{[j]}, \varphi_{i}^{[j]}, w_{i-1}^{[j]}, w_{i}^{[j]}($ rys.2).

Macierz sztywności elementu o długości $l_{\alpha}$ z rys. 2 uzyskujemy korzystając z rozwiązania równania różniczkowego płyty cienkiej. Mając tę macierz sztywności, po wyeliminowaniu przemieszczeń węzłów 1 i 2 (rys. 2) uzyskujemy macierz sztywności dowolnego elementu o numerze ,j” w postaci

$$
\boldsymbol{\Phi}^{[j]}=\mathbf{K}^{[j]} \boldsymbol{\varphi}^{[j]},
$$

gdzie $\mathbf{K}^{j}$ jest macierzą sztywności $j$-tego elementu.

Na rys. 3 schematycznie przedstawiono przekrój pasma z dowolną liczbą $N$ komórek. Niewiadomymi wielkościami są kąty obrotu w węzłach $\varphi_{j}$ oraz kąty obrotu cięciw prętów $\psi^{[j]}$.

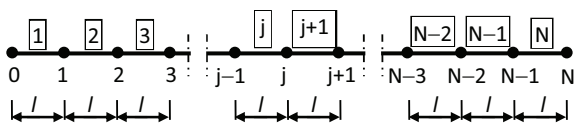

Rys. 3. Schemat fragmentu pasma płytowego

Dla dowolnego węzła $j(1 \leq j \leq N-1)$ możemy ułożyć dwa równania równowagi

$$
\phi_{j}^{j}+\phi_{j}^{j+1}=0, W_{j}^{j}+W_{j}^{j+1}=0,1 \leq k \leq N-1 .
$$

Łącznie otrzymujemy jednorodny układ równań (przy jednorodnych warunkach brzegowych pasma), w postaci

$$
\mathbf{K} \varphi=0,
$$

gdzie K jest macierzą sztywności pasma o elementach będących funkcją poszukiwanych wartości krytycznych siły ściskającej pasmo, a $\varphi$ jest jednokolumnową macierzą uogólnionych przemieszczeń.

Z warunku Det $\mathbf{K}=0$, dla danych: $N, \eta$ możemy wyznaczyć kolejne wartości sił krytycznych, powodujących utratę stateczności pasma. W pracy przedstawiono wyniki dla różnych typów warunków podparcia pasma. 